\title{
Students' Attitude towards Distance Learning at Al-Quds Open University/ Tulkarem Educational Region
}

\author{
Ahmed Awad Amin Mahmoud / Raba' \\ Associate Professor in TEFL, An-Najah National University/Nablus/ Palestine \\ Faculty of Education and Teacher Training, Curriculum and Instruction Department, TEFL Section
}

\begin{abstract}
Students' Attitude towards Distance Learning at Al-Quds Open University/Tulkarem Educational Region" The aim of this study is to examine the students' attitude towards open learning at Al-Quds Open University. To achieve this aim, the researcher used a 30-item questionnaire which was distributed among 92 male and female students (2\% of the whole population) who were chosen randomly from four educational specializations: Education, social service, administration and technology. The researcher used different statistical procedures such as means and percentages, independent paired t-test and the one way ANOVA test to analyze the necessary data for the research. Results revealed that students highly value distance learning system because it offers a good opportunity for higher education to a large number of students who want to pursue their education by overcoming the spatial, economical, and social barriers. It also provides self - directedness and autonomous learning opportunities. In the light of these findings, the researcher recommended the consideration of lack of campus activities and rarity of instructor-student interaction for a viable distance learning system.
\end{abstract}

Keywords: Students' Attitude, Distance Learning, Al-Quds Open University

\section{Introduction}

Distance learning is a unique philosophy that takes the learner's needs into consideration. It cherishes the individual's rights for equal educational opportunities by employing methods and techniques that concentrate on the learners' differences. This type of learning is considered a student centered method of teaching where the student chooses what to learn, how, when to start and when to end. The learner can work on his own pace and take his own decisions. (Al kilani, 2001)

Distance learning is a term that includes a number of alternative educational systems and has been known in different forms that include the following: (Al- Quds Open University, 1986). The first form is distance learning which is often used to replace open learning. It is defined by Dooley, Lindner and Dooley (2005) as the type of education that is appealing to learners whose responsibilities do not allow them to take advantage of traditional and face- to - face methods. Such learners are usually adults with families, full and part time employees, living in rural areas and unable to afford full time study, or they can be military personnel who want the flexibility to take courses that are not bound by time or place. The second form is external studies, an Australian term used to refer to a system of education where two form of education are presented; traditional and distance. The university or the institution provides form of distance learning courses in addition to its in campus, face -to - face programmes. The third form which can be considered as the oldest one is the correspondence education. In this type of distance education, the educational material is sent to students via mail. Finally, the last form is the independent study which is according to Hajji ( 2003) is an American model that enables students to pursue their higher education free from restriction of time, space, cost or any other unnecessary inherent in the conventional system.
The first Open University was established in England in 1970s which according to Ural (2007) has been very successful in providing flexibility and technological educational environments and it had an important role in the development of distance education system. Alongside with the Open University (UK) are the UNED (Spain) and UNED (Costa Rica), Athabasca University (Canada) and the CCTU (China). In the Arab world this experience was late and not appealing to the Arab students' expectations. One of the pioneer establishments is Al-Quds Open University in Palestine which was established in 1985 as a response and solution for the Palestinians' increased demand for higher education under the occupation circumstances. (Nashwan, 1997)

The number of universities that use open learning system has increased over the years. The estimated number of these universities according to Kilani (2001) is 900 university and educational institutions. The reason behind this increase relies in the benefits and merits of open learning opposed to traditional learning. Open University practice creates a second chance for those who are unable to complete their higher education such as women as revealed by Jauhiainen, Nori and Alho- Malmelin (2007).

The ability to afford for large number of students is one of the main characteristics of open learning. This system provides opportunities for those welling to enroll in higher education system but afford it because of the increase demand for higher education in a fast growing world. Contrary to the traditional university, the Open University can tackle the problem of huge numbers of students which require physical states, equipments, libraries, research laboratories and above all a large number of well- trained faculty and staff by the employment of technological developments such as the multi- media equipment and the internet. A good example is Anadoulu University where 


\section{International Journal of Science and Research (IJSR) \\ ISSN (Online): 2319-7064 \\ Index Copernicus Value (2013): 6.14 | Impact Factor (2014): 5.611}

there are about 1,100,000 students enrolled in 7 Bachelor's and 28 Associate's Degree programmes. (Tunckan, 2007).

Ural (2007) agrees with Tunckan (2007) by describing the Anadoulu's University's ability to afford for the massive number of students requiring higher education. As the university offers 34 different programmes in many subjects through printed materials, television programmes and academic counseling, the estimated number of students registered last year reached 600000

\section{Reviewing Related Literature}

Shahin (2008) investigates the relationship between student characteristics including learning styles and their perceptions and satisfactions in web-based courses in higher education. This investigation used Kolb's learning styles inventory and Walker's distance education learning environment instrument plus demographic questions to survey 279 students in five web-based undergraduate courses in a Midwestern universities. The study finds that the three dimensions of Moore's Transactional Distance Theory may be linked with Kolb's two dimensional views of individual learning styles. The researcher recommended designing courses that accommodate multiple leaning styles with variety on all dimensions of transactional distance.

Bandalaria (2008) discusses the impact of ICTs on open and distance learning (ODL) in the Philippine. In this paper the researcher examines how ICTs have influenced the development of ODL in this country ,as well as, the different stages or generations of distance education in the Philippines ,which are characterized by the dominant technology used for the delivery of instructional content and student support service .He also described the different ICTs used in ODL and their specific application to the various facets of this mode of delivery .In addition ,he included an examination of how quality of education is ensured in a technology -driven system of teaching and learning, which includes the employment of the "quality circle approach" in the development of courses and learning packages and the provision of appropriate technologies to perform academic processes and achieve institutional goals .

Ibara (2008) in his study discussed Open and Distance learning as alternatives for higher education in Nigeria. He also addressed the importance of open and distance education which is necessary to meet the demand of time for higher conventional education especially that the demand is higher than what the system can cope with. The researcher concluded that considering the level of infrastructural decay in the conventional higher education has become imperative for the realization of the primary objectives of higher education.

Tao and Yeh (2008) in their study of the teachers' perception toward distance education issues aimed to clarify teachers' perceptions on key distance education issues and to develop a discernible typology of different groups of teachers based on their perceptions. The target was teachers in information related departments in Taiwan's colleges who were more familiar with current technology. To achieve their goals the researchers used factor and cluster analysis to derive the typology. The results of this study indicated that five higher - level issues constructs emerged from the factor analysis; learning effect, customization, administrative challenges, geographic and resource integration and instructional design challenges. Four groups of teachers; namely the skeptics, the optimistic, the mild- promising group and the outlier were identified using cluster analysis of teachers' perception on the five higher level issue constructs.

Ural (2007) investigated the views of the doctoral students at traditional universities on the use of distance education systems, technologies and independent learning in Turkey where there is a great demand for higher education. The researcher indicated that there is a great demand for higher education in Turkey and the use of distance education systems and technologies in traditional universities is not common. He added that those traditional universities can make use of the distance education systems and technologies in certain lectures and cope with the pressure of the increasing number of students and they can affect the mega Turkish education system in a positive way. He concluded that the findings of his research indicated that doctoral students do not have a positive attitude towards the use of distance education system and technologies and they did not agree with the idea that distance education systems can support independent learning .

Mashhour (2007) presented a distance education model for Jordanian students based on empirical study. In his study on a sample of Jordanian students in distance education system the researcher addressed the need of such education at the national level .The response of his sample showed that distance education is offering a viable and satisfactory alternative to those who cannot enroll in regular residential education. The study also showed that the short -comings of the regular and the current form of distance education could be overcome by the use of modern technology.

Rosi and Hopkinse (2007) contrasted two distance foreign language programmes developed at two European institutions of higher education (the modern language program at the open university, UK and the English program at the Universidad Oberta de Catalunya, Spain) as instances of two pedagogical models used to address the many challenges posed by teaching language at a distance The analysis of the two approaches revealed that the pedagogical choice made by both universities are in great measure determined by the historical and cultural contexts in which both institutions are embedded

Nartgun (2007) carried a diagnostic study of Open University students' perceptions about the problem of distance education application. The subjects of this study are the open faculty students $(n=45)$ who attend its courses Data were collected through interviews and indicated that students preferred mostly the open learning as they worked at different offices. They also pointed out that most of the students had positive attitudes towards the university. However, they reported that they had difficulty in studying by themselves and that they believed they would have problems in finding a job in future. 


\section{International Journal of Science and Research (IJSR) \\ ISSN (Online): 2319-7064}

Index Copernicus Value (2013): 6.14 | Impact Factor (2014): 5.611

Jauhiainen, Nori and Alho (2007) described and analyzed the background and goals of student at the Finnish open university in the beginning of the twentieth century .To achieve their goals the researchers used statistics based on students' records of the Finish Open University in 2000 and of their stories, in addition to 106 written education autobiographies .As a result of the quantitive analysis they found that a typical student at the university is a female at the age 25 to 30, unmarried, childless ,working in a service occupation with low income, secondary school graduate and living in a town in the south of Finland .On the basis of the autobiographies the students were classified into four types, career orientated, graduate orientated ,seekers of change and studying as a way of life .

Ludher and Lee (2007) conducted a study on the socioeconomic context of home- based learning by women in Malysia. The findings of the study illustrated the urgent need for urban and rural learners alike to be served by up to date ICT equipped learning centers. In addition, it indicated that ICT based methods can only become viable supplier of distance education and learning to women in Malysia when the social and gender-related challenges faced by this vulnerable sector of society have been overcome.

Bernard and Abrami (2006) in their meta-analysis employ a theoretical framework in quantitively synthesizing empirical studies that investigated the effects of distance education (DE) versus classroom instruction on undergraduate student achievement. The results indicated that the effect sizes for synchronous instructor-directed DE were consistence and not significantly different from zero. Where as in asynchronous DE, media supporting independent learning was generally less effective than supporting collaborative discussion among students. Follow up analysis of asynchronous DE finding was framed in terms of three patterns of interaction, student -content, student instructor and student.

Mutlu (2005) presented a descriptive study of the design and development of the E-learning services in the open education system in Turkey. The researcher concluded that the structure of the Open Education E-leaning services are flexible to the extent that students can study efficiently respecting the distance education regulation, follow the books, television programs and practice software, ask questions to the academic facilitators and get reply from them ,as well as , take trial exams to evaluate all their efforts .

Darwazah (1986) conducted a study that aimed to investigate variables affecting university academic achievement in distance versus conventional education setting. The findings of the study showed that the university academic achievement in both types of education have been affected significantly by similar variables ,however ,the university academic achievement in both types of education have not been affected significantly by these variables work responsibility and the university academic level. Moreover, gender has a significant effect on the university academic achievement in distance but not in conventional education setting and in favor of females.

\section{Problem of the Study}

From the researcher's experience as a lecturer at An-Najah National University and at Al- Quds Open University, he found that students' attitudes towards distance learning vary which affect their success and progress and in some cases leads to their withdrawal. Therefore he found it necessary to investigate this issue by asking the following question: What is the students' attitude towards distance learning in Al-Quds Open University?

\section{Significance of the Study}

This study sought to find out the students' attitude towards distance learning in Al- Quds Open University. Secondly, it could be of great value to the concerned authorities as one of the few studies in the field up to the researcher's knowledge. It could provide information of great importance by identifying the roles of gender, specialization and the academic level variables on the students' attitude towards open learning in Al- Quds Open University. Furthermore, it could be used as a pinpoint for further studies in the field - tackling issues which were not dealt with in the study and using different samples and environments.

\section{Aim of the Study}

This study aimed to find out the students' attitude towards distance learning at Al- Quds Open University.

\section{Questions of the Study}

This study aimed to answer the following questions:

1) What is the students' attitude towards distance learning at Al- Quds Open University?

2) Are there any statistical significant differences in students' attitude towards distance learning at Al- Quds Open University due to gender variable?

3) Are there any statistical significant differences in students' attitude towards distance learning at Al- Quds Open University due to specialization variable?

4) Are there any statistical significant differences in students' attitude towards distance learning at Al- Quds Open University due to academic level variable?

\section{Limitations of the Study}

This study was limited to Al- Quds Open University students, Tulkarm Area whose total number was 4477 male and female students. The chosen students were attending the university during the second semester of the academic year 2014-2015.

\section{Procedures of the Study}

\section{Population of the Study}

The population of this study consisted of Al-Quds Open University students /Tulkarm area. The total number is (4477) students: 1750 are males and 2727 are females according to the university statistics.

\section{Sample of the Study}

The sample of the study consisted of 92 male and female students ( $2 \%$ of the whole population). The sample was chosen randomly from the whole population. Tables 1, 2and 3 show the distribution of the sample according to gender, specialization and academic level respectively. 


\section{International Journal of Science and Research (IJSR) \\ ISSN (Online): 2319-7064 \\ Index Copernicus Value (2013): 6.14 | Impact Factor (2014): 5.611}

Table 1: Sample distribution due to gender variable

\begin{tabular}{|c|c|c|}
\hline Gender & Frequency & Percentage \\
\hline male & 42 & 46.2 \\
\hline female & 50 & 53.8 \\
\hline total & 92 & $100 \%$ \\
\hline
\end{tabular}

Table 2: Sample distribution due to specialization variable

\begin{tabular}{|c|c|c|}
\hline Specialization & Frequency & Percentage \\
\hline Faculty of education & 36 & 39.1 \\
\hline Social service & 9 & 9.8 \\
\hline Administration & 33 & 35.9 \\
\hline Technology & 14 & 15.2 \\
\hline total & 92 & $100 \%$ \\
\hline
\end{tabular}

Table 3: Sample distribution due to academic level variable

\begin{tabular}{|c|c|c|}
\hline Academic level & Frequency & Percentage \\
\hline 1st year & 20 & 21.7 \\
\hline $2^{\text {nd }}$ year & 26 & 28.3 \\
\hline 3rd year & 24 & 26.1 \\
\hline $4^{\text {th }}$ year & 22 & 23.9 \\
\hline total & 92 & $100 \%$ \\
\hline
\end{tabular}

\section{Instrument of the Study}

The researcher used a 30- item questionnaire which was designed for the purpose of the study. Likert scale was used for the participants' responses

$\begin{array}{ll}\text { Positive items: } & \\ \text { Strongly agree } & 5 \text { degrees } \\ \text { Agree } & 4 \text { degrees } \\ \text { Neutral } & 3 \text { degrees } \\ \text { Disagree } & 2 \text { degrees } \\ \text { Strongly disagree } & 1 \text { degree } \\ \text { Negative items: } & \\ \text { Strongly agree } & 1 \text { degree } \\ \text { Agree } & \text { 2degrees } \\ \text { Neutral } & \text { 3 degrees } \\ \text { Disagree } & 4 \text { degrees } \\ \text { Strongly disagree } & 5 \text { degrees }\end{array}$

Validity of the instrument

To affirm the validity of the instrument, the researcher gave it to a committee of referees which consisted of five members from the teaching faculty. The researcher asked them to affirm the suitability of the tool for the study purposes. In the light of the committee notes and the adoption of the items which was $70 \%$ of the committee agreed upon, the number of the items showing students attitudes towards distance learning at Al-Quds Open University reached 30 items after the adjustment and modification and the deletion of 4 items from the designed questionnaire which was formed of 34 items.

Reliability of the instrument:

For testing reliability of the instrument the researcher used Cronbach Alpha in which the reliability factor reached 79\% and this degree is relatively high and fulfills the goals of the study.
This study descriptive that aimed to investigate students' altitude towards distance learning at AL-Quds Open University in the second semester of the year 2014/2015. This study included the following variable:

1. Independent variables

a) Gender variable which has tow levels: male /female.

b) Specialization variable and it has four levels:

* Faculty of education * Social service * Administration * Technology

c) Academic variable and it has four levels:

$1^{\text {st }} 2^{\text {nd }}$ year $3^{\text {rd }}$ year $4^{\text {th }}$ year

2. Dependent variables

The students' altitude towards distance learning at Al-Quds Open University.

\section{Statistical Analysis}

For the sake of analyzing data the researcher used:

1) Means and percentages

2) Independent paired t- test

3) One way ANOVA

\section{Procedures of the Study}

After affirming the validity and the reliability of the instrument, the researcher conducted the following procedures:

1) Preparing the final copy of the instrument

2) Distributing the questionnaire after taking the official approvals.

3) Collecting the distributed questionnaire, coding the data in special tables for the statistical analysis.

4) Extracting the results, analyzing and discussing them to present the recommendations.

\section{Statistical Analysis and Results:}

This study aimed to investigate AL-Quds Open University students' attitudes towards distance learning. In addition it sought to determine the effect of the following variables: gender, specialization and academic level on the students' attitudes. The data of the study were statistically analyzed and the results were as follows:

For the purpose of interpreting the findings of the study, the following percentages and ranks were referred to.

$\begin{array}{lc}\text { Rank } & \text { percentage } \\ \text { Very poor } & \text { Below } 50 \% \\ \text { Poor } & 50-59.9 \% \\ \text { Medium } & 60-69.9 \% \\ \text { Good } & 70-70.9 \% \\ \text { Very good } & 80 \% \text { and more }\end{array}$

\section{Results and Discussion}

To answer the first question of the study," What is the students' attitude towards distance learning at Al-Quds Open University?" the researcher used means, percentages and degree level for each item and for the total degree for the questionnaire. Table 4 shows the results.

The design of the study:

Table 4: Means, percentage and the degree level for each item

\begin{tabular}{|c|c|c|c|c|c|}
\hline Serial $N$ & Numbers & Item & Means & $\%$ & attitudes \\
\hline 1. & 17 & Large number of students can join distance learning system. & 4.35 & 86.96 & Very good \\
\hline
\end{tabular}




\section{International Journal of Science and Research (IJSR) \\ ISSN (Online): 2319-7064}

Index Copernicus Value (2013): 6.14 | Impact Factor (2014): 5.611

\begin{tabular}{|c|c|c|c|c|c|}
\hline 2. & 1 & Distance learning system is flexible due to academic and administrative organization. & 4.21 & 84.13 & Very good \\
\hline 3. & 9 & Distance instruction uses educational technology at a wide range & 4.18 & 83.70 & Very good \\
\hline 4. & 11 & Depending on educational aids decreases depending on teachers & 4.17 & 83.48 & Very good \\
\hline 5. & 20 & $\begin{array}{l}\text { Distance learning system creates open minded students who can cope with } \\
\text { educational development }\end{array}$ & 4.08 & 81.52 & Very good \\
\hline 6. & 18 & The educational establishment is as responsible as the supervisor for teaching students & 4.05 & 81.09 & Very good \\
\hline 7. & 7 & $\begin{array}{l}\text { Organizing the educational material guarantees the interaction between the learner and } \\
\text { the material }\end{array}$ & 3.98 & 79.57 & good \\
\hline 8. & 6 & Distance learning system enhances the learner's motivation & 3.91 & 78.26 & good \\
\hline 9. & 8 & $\begin{array}{c}\text { Distance learning system offers good opportunity to the learner to choose the major he } \\
\text { wants, the time and the way of studying }\end{array}$ & 3.90 & 78.04 & good \\
\hline 10. & 13 & The learner is able to evaluate his learning due to pre- assigned objectives. & 3.87 & 77.39 & good \\
\hline 11. & 10 & $\begin{array}{c}\text { The learner in distance learning system is an independent learner who takes the } \\
\text { responsibility of his learning }\end{array}$ & 3.84 & 76.74 & good \\
\hline 12. & 26 & Distance learning system employs modern technology that attracts learner's attention & 3.78 & 75.65 & good \\
\hline 13. & 19 & Distance learning system overcomes geographical distances & 3.75 & 75.00 & good \\
\hline 14. & 22 & $\begin{array}{l}\text { The student's main educational relationship is with his academic supervisor in the } \\
\text { distance learning system }\end{array}$ & 3.73 & 74.57 & good \\
\hline 15. & 21 & The academic supervisor is not involved in the design of the course material & 3.70 & 73.91 & good \\
\hline 16. & 16 & Distance learning system is based on the division of labor & 3.60 & 71.96 & good \\
\hline 17. & 2 & $\begin{array}{l}\text { Distance learning system enables students in remote areas to pursue their high } \\
\text { education }\end{array}$ & 3.57 & 71.30 & good \\
\hline 18. & 25 & Distance learning system overcomes economical and social barriers & 3.53 & 70.65 & good \\
\hline 19. & 5 & It is essential to be daily in contact with the & 3.40 & 68.04 & Neutral \\
\hline 20. & 14 & The interaction between students in distance education promotes their experience & 3.38 & 67.61 & Neutral \\
\hline 21. & 24 & $\begin{array}{l}\text { The method of teaching in the open university is an extension of the previous } \\
\text { educational experience of the student }\end{array}$ & 3.37 & 67.39 & Neutral \\
\hline 22. & 4 & $\begin{array}{l}\text { Fixed timetables of assessment and examination is the pre dominant mode of teaching } \\
\text { in the open university }\end{array}$ & 3.36 & 67.17 & Neutral \\
\hline 23. & 30 & The relationship between student and the academic supervisor is a unique one & 3.21 & 64.13 & Neutral \\
\hline 24. & 12 & Distance learning system offers specialized knowledge and skills & 3.18 & 63.70 & Neutral \\
\hline 25. & 15 & Cost is relatively high in distance learning system & 3.13 & 62.61 & Neutral \\
\hline 26. & 3 & The student is expected to reside near the university in Distance learning system & 3.02 & 60.43 & Neutral \\
\hline 27. & 29 & $\begin{array}{l}\text { It is essential for the student in distance learning system to be daily in contact with his } \\
\text { academic supervisor and classmates }\end{array}$ & 3.02 & 60.43 & Neutral \\
\hline 28. & 28 & The university consists of a set of buildings provided with a variety of facilities & 3.01 & 60.22 & Neutral \\
\hline 29. & 23 & Class -based lectures are essential in distance learning system & 2.96 & 59.13 & Low \\
\hline 30. & 27 & Students in distance learning system are not highly motivated & 2.72 & 54.35 & low \\
\hline & & Total & 3.59 & $\% 72$ & Very good \\
\hline
\end{tabular}

Table (4) reveals that Al-Quds Open University students' attitudes towards distance learning were very high on items $(17,1,9,11,20$, and 18), the percentage of response was (more than 80\%). This result is in the line with (Al kilani, 2001), Hajji (2003), Tunckan (2007) and Ibara (2008). However such high attitudes contradicted with Ural (2007). As for the items $(6,7,13,10,27,19,22,21,16,2,25)$, received a high degree, the percentage of response was in between (7079.\%). On one hand this result agrees with Mutlu (2005), on the other hand this result disagrees with Nartgun (2007). According to items $(5,14,24,4,30,12,15,3,29,28)$, received a medium level, the percentage of response was between (60$69 . \%)$.The rest of the items $(23,27)$ received a poor level, the percentage of response was between (50-39.).The total degree for the questionnaire was good, the percentage of response was $72 \%$.The findings of the questionnaire reveal that students' attitudes towards distance learning is very high . These findings disagreed with Ural (2007) who found the reverse result, but it agrees partially with Isik, Karakis and Guler (2010) who revealed that there is a general positive attitude towards distance learning. The majority of students found themselves more comfortable in distance learning than traditional learning and they also found that distance learning was more efficient than traditional learning. However the attitudes of females towards web based distance learning were found to be significantly more positive than males.

\section{Results concerning the hypotheses:}

1. The first hypothesis," There were no statistical significant differences at $\alpha=.05$ in students' attitude towards open learning at AL-Quds Open University due to gender. The researcher used the independent T-test to analyze the data from the questionnaire as shown in table (5).

Table 5: The independent T-test results in the students' attitude towards distance learning due to gender

\begin{tabular}{|c|c|c|c|c|c|c|}
\hline \multirow[t]{3}{*}{ gender } & \multicolumn{2}{|r|}{ males } & \multicolumn{2}{|r|}{ females } & t-test & significance \\
\hline & \multicolumn{2}{|r|}{ Number 42} & \multicolumn{2}{|r|}{50} & & \\
\hline & mean & Standard deviation & means & Standard deviation & \multirow[t]{2}{*}{0.51} & \multirow[t]{2}{*}{0.61} \\
\hline & 3.61 & 0.34 & 3.58 & .36 & & \\
\hline
\end{tabular}




\section{International Journal of Science and Research (IJSR) \\ ISSN (Online): 2319-7064 \\ Index Copernicus Value (2013): 6.14 | Impact Factor (2014): 5.611}

The results of the table showed that the computed t-test value was $(0.51)$ and the significance was $(0.61)$ which means that there were no statistical significant differences in students' attitude towards open learning due to gender variable. This means that both males and females have almost the same attitudes. On one hand, this result agrees with Dhiman, Birbal and Bhim (2014) who revealed that students have high attitude towards distance learning and their attitude scores did not differ significantly with their personal variables such as, gender. On the other hand, this result contradicts with Darwazah (1986) and Isik, Karakis and Guler (2010) who found that the attitudes of females towards web based distance learning were found to be significantly more positive than males.

2. To test the second hypothesis," There were no statistical significant differences at $(\alpha=0.05)$ in students' attitude towards distance learning due to specialization." The researcher used one way (ANOVA) test as shown in tables $(6$, $7)$.

Table 6: The means results on the differences in students' attitude towards distance learning due to specialization

\begin{tabular}{|c|c|c|c|c|}
\hline specialization & $\begin{array}{c}\text { Faculty of } \\
\text { education }\end{array}$ & $\begin{array}{c}\text { Social } \\
\text { Sciences }\end{array}$ & Administrations & Technology \\
\hline & 36 & 9 & 33 & 14 \\
\hline & 3.51 & 3.55 & 3.64 & 3.71 \\
\hline
\end{tabular}

Table 7: The one way ANOVA results on the differences in the degree of evaluation in students' attitude towards distance learning due to specialization

\begin{tabular}{|c|c|c|c|c|c|c|}
\hline Areas & source & $d f$ & Sum of & $\begin{array}{c}\text { Mean } \\
\text { square }\end{array}$ & $f$ & significance \\
\hline & Within groups & 3 & 0.519 & 0.173 & 1.40 & 0.24 \\
\hline & Inside groups & 88 & 10.832 & 0.123 & & \\
\hline & total & 91 & 11.351 & & & \\
\hline
\end{tabular}

Table 7 reveals that the significance is $.24>0.05$ which means that there were no significance differences in students' attitude towards distance learning at AL-Quds Open University due to specialization. This result agrees with Dhiman, Birbal and Bhim (2014) who revealed that students have high attitude towards distance learning and their attitude scores did not differ significantly with their personal variables such as, gender and stream of study.

3. Results of the third hypothesis " There were no statistical significant differences at $(\alpha=0.05)$ in students' attitude towards distance learning at Al-Quds open university due to the academic level. To do that, the researcher used the One Way ANOVA test as shown in tables $(8,9)$.

Table 8: The results on the differences in the students' attitude towards distance learning due to academic level

\begin{tabular}{|c|c|c|c|c|}
\hline Academic level & $\begin{array}{c}1 \text { st year } \\
\mathrm{N}=26\end{array}$ & $\begin{array}{c}2^{\text {nd }} \\
\mathrm{N}=26\end{array}$ & $\begin{array}{c}3^{\text {rd }} \\
\mathrm{N}=24\end{array}$ & $\begin{array}{c}4^{\text {th }} \\
\mathrm{N}=22\end{array}$ \\
\hline & 3.51 & 3.64 & 3.59 & 3.61 \\
\hline
\end{tabular}

Table 9: The one way ANOVA results on the differences in the students' attitude towards distance learning due to academic level

\begin{tabular}{|c|c|c|c|c|c|c|}
\hline areas & source & $\mathrm{df}$ & $\begin{array}{c}\text { Sum of } \\
\text { squares }\end{array}$ & $\begin{array}{c}\text { Mean } \\
\text { square }\end{array}$ & $\mathrm{f}$ & significance \\
\hline & Within groups & 3 & 0.196 & 0.065 & 0.51 & 0.67 \\
\hline & Inside groups & 88 & 11.155 & 0.127 & & \\
\hline & total & 91 & 11.351 & & & \\
\hline
\end{tabular}

Table 9 reveals that the significance was $0.67<0.05$ which means that there were no significant differences in students' attitude towards distance learning at Al-Quds Open University due to the academic level. Up to the researcher's knowledge no other local, regional or global study consider the variable of the academic level for the BA degree.

\section{Conclusion}

The study showed that distance learning is offering a good opportunity for higher education to a great number of students who want to pursue their education by overcoming the spatial, economical, and social barriers. This ability stems from the educational system that offers organized educational materials. It also provides self - directedness and autonomous learning opportunities. However, they regret some disadvantages such as the lack of campus activities and rarity of instructor interaction.

\section{Recommendation}

In the light of the findings of the study, the researcher would like to suggest the following recommendations.

1) The extensive and appropriate use of the internet and modern technologies can make up the lack of campus activities and the rarity of student - instructor interaction.

2) Conduct similar studies for further investigation of instructors' attitudes towards distance education

3) As no other studies consider the variable of academic level for the first university degree, it could be fruitful to tackle it for further studies.

\section{References}

\section{English References}

[1] Bandalaria, Melinda. (2008)."Impact of ICTs on Open and Distance Learning in a Developing Country Setting". International Review of Research in Open and Distance Learning, VOL. 8, No. 1.

[2] Dooley, Kim, Lindner, James and Dooley, Larry. (2005). Advanced Methods in Distance Education. Information Sciences Publishing, USA.

[3] Dhiman Kar, Birbal Saha, Bhim Chandra Mondal (2014) Attitude of University Students towards Elearning in West Bengal Science and Education Publishing. American Journal of Educational Research, 20142 (8), pp 669-673. DOI: 10.12691/education-2-8-16

[4] Ibarra, Emmanuel. (2008). "Open and Distance Learning: an emerging system for alternative higher education in Nigeria". Turkish Online Journal of

\section{Volume 5 Issue 2, February 2016}




\section{International Journal of Science and Research (IJSR) \\ ISSN (Online): 2319-7064 \\ Index Copernicus Value (2013): 6.14 | Impact Factor (2014): 5.611}

Distance Education.VOL. 9, No. 1, article 7 p. 118122.

[5] Isik A; Karakis, R and Guler, G. (2010) Postgraduate students' attitudes towards distance learning (The case study of Gazi University) Procedia - Social and Behavioral Sciences Volume 9, 2010, Pages 218-222

[6] Jauhiainen, Arto, Nori, Hanna and Akho-Malmelin, Marika.(2007). "Various portraits of Finnish open university students." Scandinavian Journal of Educational Research, VOL, 51, No. 1p. 23-39.

[7] Loh, Ludher and Lee, Lee. (2007)." The socioeconomic content of home- based learning by women in Malysia". Distance Education, VOL. 28, No. 2, p. 179-193.

[8] Lou, yipping, Bernard, Robert $M$ and Abrami, Philip (2006)"Media and Pedagogy in undergraduate distance education: A Theory-Based Meta-Analysis of Empirical Literature." Educational Technology Research and development .V54 N2.Association for Educational communication Technology Springer. PP141-169

[9] Mashhour, Ahmad.(2007). "A distance education model for Jordanian students based on an empirical study". Bahrain University, Bahrain.

[10] Mutlu, M.Emin. (2005). "Design and Development of E-learning Services in the Open Education System in Turkey". Anadoulu University, ryilmaz@anadolu.edu.tr

[11] Nartgun, Senay. (2007)."A diagnostic study of open university students' perceptions about the problem of distance education application". Online Submission.

[12] Al-Quds Open University. (1986). An Introduction to Open Learning Systems of Higher Education. Amman, Jordan.

[13] Rosi-Sole, Christina and Hopkins, Joseph. (2007)." Contrasting two approaches to distance language learning". Distance Education Journal, VOL28, No. 3, and p.351-370.
[14] Sahin, Sami. (2008)."The relationship between student characteristics, including styles and their perceptions and satisfaction in web -based courses in higher education ". Turkish Online Journal of Distance Education.VOL. 9, No. 1, p. 123-138.

[15] Tao, Yu-Hui, Rosah, Yeh and Chu Chen. (2008)."Typology of teacher perception toward distance education issues". Computers and Education Journal, VOL. 50, No. 1, p. 23-36.

[16] Tunckan, Ergun.( 2007). "Structural dimensions and functions of student centers in the open education faculty practices". Turkish Online Journal of Distance Education. VOL. 8, No. 4, article 13.

[17] Ural, Ozona. (2007). "Attitudes of graduate students toward distance education technologies and independent learning". Turkish Online Journal of Distance Education.VOL. 8, No.4, article 3.

\section{Arabic References}

[18] Darwazah, Afnan. (1986). "Awamel tu'ather ala Altahseel Al- academei Al- Jamie fi Nitham Ata'leem Al- maftouh Muqabel Netham Ata'leem Ataqlidie". Majalat Itihad Al-Jami'at Al-arabia, Amman, Jordan, VOL. 1, p.207-229.

[19] Haji, Ahmad. (2003).Ata'leem Al-jami'ee Almaftouh an Bu'd. Alam Alkutub, Cairo, Egypt

[20] Kilani, Taiseer. (2001).Nitham Ata'leem Al- maftouh wa Ata'leem an Bu'd wa Jawdatihi Annaw'ia. Asharika Al- Masria Al- Alamia Lenashr, Cairo, Egypt.

[21] Nashwan, Ya'qub. (1998). Ata'lum an Bu'd wa Ata'leem Al- Jamie Al- Maftouh. Al-Quds Open University.

\section{Appendix 1}

\section{Questionnaire}

\section{Dear Students:}

This questionnaire is composed of two parts: The first part is about personal information and the second part is about the items of the questionnaire. Go through the two parts carefully and then fill the needed information in the right position. This questionnaire is used to collect data necessary for the research entitled: "Students' Attitude towards Distance Learning at Al Quds Open University/ Tulkarem Educational Region."

Part I

Personal Information

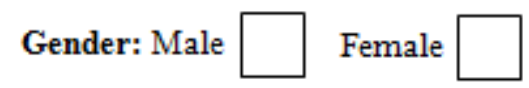

Specification:

* Faculty of education * Social service * Administration * Technology

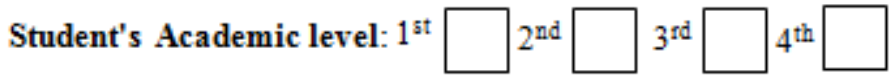

Thanks for the cooperation 


\section{International Journal of Science and Research (IJSR) \\ ISSN (Online): 2319-7064}

Index Copernicus Value (2013): 6.14 | Impact Factor (2014): 5.611

\section{Student's Attitude towards Distance Learning in Al Quds Open University}

\begin{tabular}{|c|c|c|c|c|c|c|}
\hline N. & Item & Disagree & $\begin{array}{l}\text { Strongly } \\
\text { Disagree }\end{array}$ & Neutral & Agree & $\begin{array}{c}\text { Strongly } \\
\text { Agree }\end{array}$ \\
\hline 1) & Large number of students can join distance learning system. & & & & & \\
\hline 2) & Distance learning system is flexible due to academic and administrative organization. & & & & & \\
\hline 3) & Distance instruction uses educational technology at a wide range & & & & & \\
\hline 4) & Depending on educational aids decreases depending on teachers & & & & & \\
\hline 5) & $\begin{array}{c}\begin{array}{c}\text { Distance learning system creates open minded students who can cope with educational } \\
\text { development }\end{array}\end{array}$ & & & & & \\
\hline 6) & The educational establishment is as responsible as the supervisor for teaching students & & & & & \\
\hline 7) & $\begin{array}{l}\text { Organizing the educational material guarantees the interaction between the learner and } \\
\text { the material }\end{array}$ & & & & & \\
\hline 8) & Distance learning system enhances the learner's motivation & & & & & \\
\hline 9) & $\begin{array}{c}\text { Distance learning system offers good opportunity to the learner to choose the major he } \\
\text { wants, the time and the way of studying }\end{array}$ & & & & & \\
\hline 10) & The learner is able to evaluate his learning due to pre- assigned objectives. & & & & & \\
\hline 11) & $\begin{array}{l}\text { The learner in distance learning system is an independent learner who takes the } \\
\text { responsibility of his learning }\end{array}$ & & & & & \\
\hline 12) & Distance learning system employs modern technology that attracts learner's attention & & & & & \\
\hline 13) & Distance learning system overcomes geographical distances & & & & & \\
\hline 14) & $\begin{array}{l}\text { The student's main educational relationship is with his academic supervisor in the } \\
\text { distance learning system }\end{array}$ & & & & & \\
\hline 15) & The academic supervisor is not involved in the design of the course material & & & & & \\
\hline 16) & Distance learning system is based on the division of labour & & & & & \\
\hline 17) & Distance learning system enables students in remote areas to pursue their high education & & & & & \\
\hline 18) & Distance learning system overcomes economical and social barriers & & & & & \\
\hline 19) & It is essential to be daily in contact with the academic supervisor in distance education & & & & & \\
\hline 20) & The interaction between students in distance education promotes their experience & & & & & \\
\hline 21) & $\begin{array}{l}\text { The method of teaching in the open university is an extension of the previous } \\
\text { educational experience of the student }\end{array}$ & & & & & \\
\hline 22) & $\begin{array}{l}\text { Fixed timetables of assessment and examination is the pre dominant mode of teaching in } \\
\text { the open university }\end{array}$ & & & & & \\
\hline 23) & The relationship between student and the academic supervisor is a unique one & & & & & \\
\hline 24) & Distance learning system offers specialized knowledge and skills & & & & & \\
\hline 25) & Cost is relatively high in distance learning system & & & & & \\
\hline 26) & The student is expected to reside near the university in Distance learning system & & & & & \\
\hline 27) & $\begin{array}{l}\text { It is essential for the student in distance learning system to be daily in contact with his } \\
\text { academic supervisor and classmates }\end{array}$ & & & & & \\
\hline 28) & The university consists of a set of buildings provided with a variety of facilities & & & & & \\
\hline 29) & Class -based lectures are essential in distance learning system & & & & & \\
\hline 30) & Students in distance learning system are not highly motivated & & & & & \\
\hline
\end{tabular}

